\title{
An Empirical Analysis of the Risk Taking Channel of Monetary Policy in China-Base on Evidence from Chinese Listed Bank
}

\author{
Haoteng Chen \\ School of Economics, Jinan University, Guangzhou, China \\ Email: chteng23@163.com
}

How to cite this paper: Chen, H.T. (2019) An Empirical Analysis of the Risk Taking Channel of Monetary Policy in China-Base on Evidence from Chinese Listed Bank. American Journal of Industrial and Business Management, 9, 1033-1044.

https://doi.org/10.4236/ajibm.2019.94071

Received: April 9, 2019

Accepted: April 25, 2019

Published: April 28, 2019

Copyright $\odot 2019$ by author(s) and Scientific Research Publishing Inc. This work is licensed under the Creative Commons Attribution International License (CC BY 4.0).

http://creativecommons.org/licenses/by/4.0/

(c) (i) Open Access

\begin{abstract}
After financial crisis in 2008, more and more researchers paid attention to not only the expansionary monetary policy but also the relationship between the risk-taking and monetary policy. Borio and Zhu firstly researched on risk-taking channel of monetary policy in 2008 . This article firstly reviews some literature about the risk-taking channel of monetary policy, the transmission mechanism and the influencing factors, and then selects the data of 15 representative listed Banks in China from 2007-2016 to do empirical research and draw the following conclusions. First, this article finds evidence that the risk-taking channel of monetary policy is significant in China. Expansionary monetary policy has a positive impact on banks' risk-taking. Second, macro-economic conditions and the micro characteristics of the bank can influence the transmission of risk-taking channel. Based on that, this article proposes the recommendation that monetary policy should be included in macro-prudential system to strengthen monitoring system of the bank's risk management. Besides the relationship between counter-cyclical capital regulation and monetary policy control is important.
\end{abstract}

\section{Keywords}

Monetary Policy, Bank Risk-Taking, Risk-Taking Channel of Monetary

Policy, Macro-Prudential System

\section{Introduction}

The financial crisis in 2008 caused enormous damage to the global economy reflects the fragility of the modern financial system. Even the most complete financial system in the world is vulnerable to the crisis. Looking back at this crisis, many policy makers and researchers have explored the reasons of it and tried to 
explain the fragility of the global financial system. The failure of supervision system and the complexity of the development of credit instrument market are main opinions. On the other hand, many economists have debated the long-term adoption of expansionary monetary policies before the crisis, arguing that long-term low interest rates and a loose liquidity environment lead to the accumulation of risks throughout the financial system. After the bursting of the US innovation stock bubble in 2000, some countries launched loose monetary policy to stimulate the economy. However, excessive liquidity caused some damage to financial stability. The global financial crisis shows that the currency transmission mechanism is more complicated than before. The impact is not only limited to inflation and short-term aggregate demand, but also has an influence on the risk-taking [1].

In the opinion of traditional monetary policy credit channel, monetary policy is completely neutral. So it does not incorporate financial risk into the model. It means that the financial market reacts equally to the same level of loose monetary policy and tightening monetary policy. However, after the United States implemented the loose monetary policy in 2002, excessive liquidity caused banks to take higher risks and undermine financial stability. Therefore, a study of monetary policy risk channels plays an important role in the understanding of monetary policy and financial stability theoretical guidance for monetary policy decision-making.

The report on the implementation of monetary policy in the second quarter of 2017 pointed out that the monetary aggregate should be kept stable and a variety of monetary policy tools such as quantity and price should be used comprehensively. We will strike a balance between maintaining steady growth, adjusting the structure and controlling aggregate demand, and create a neutral monetary and financial environment for supply-side structural reform [2]. Therefore, in addition to the traditional monetary policy tools, China's central bank has created a variety of monetary policies with industry orientation and structural adjustment function to promote the efficient operation of funds, improve the efficiency of financial operation and the ability to serve the real economy. Such monetary policy tools include SLF, MLF, PSL, etc. In recent years, China's commercial Banks have made innovations in inter-bank business. With the cooperation of multiple institutions, the development of inter-bank business has become an important means to expand the credit scale and broaden the source of profits [3].

For the current situation of China's banking system and the current monetary policy, it is significance to study the potential link between monetary policy and bank's risk-taking. First, with the China's market-oriented reforms, competition between banks and non-financial institutions will become increasingly fierce. Secondly, China has not achieved full interest rate liberalization yet. Therefore, monetary policymaker mainly relies on quantitative tools and non-market-oriented direct means. Finally, with the continuous advancement of the market-oriented reform process, the identification, measurement, preference and pricing of risks 
by commercial banks not only affect their investment behavior, but also play an important role in the transmission of monetary policy. This article is based on the risk-taking channel and transmission mechanism of monetary policy to study relationship between monetary policy and bank risk-taking behavior. Based on the data of 15 representative banks in China, we build a model to empirically study whether China has a risk-taking channel for monetary policy. After the analysis of the empirical result and current reality of China's macro-economic, we will put forward corresponding policy recommendations for monetary policy maker and institutional framework of macro-prudential management.

\section{Literature Review}

Risk taking channel of monetary policy was firstly presented by Borio and Zhu in a report [4]. They noticed the potential link between low interest rates and rising bank risk-taking in this report. Specifically, the risk-taking channel was defined as the impact on pricing of assets, financing costs and risk pricing from monetary policy, thereby affecting the perception of risk tolerance and financial institutions, and to further the credit of financial institutions and investment decisions, and ultimately act on financial stability and the total output. Dubecq proposed a model of risk transfer interest rates will affect the risk perception of investors that regulatory constraints in the uncertain situation could lead to market participants the risk of erroneous inference form [5]. In this case, the increase in asset prices will be interpreted as a lower overall economic risk, and in fact asset prices are driven by the high risks borne by financial intermediaries. Dell'Ariccia et al. studied the relationship between loose monetary policy and bank risk taking through a static model. Under long-term loose monetary conditions, banks' risk appetite will increase. However, the net effect of monetary policy depends on interest rate conduction, risk transfer and balanced capital structure [6]. When commercial banks can adjust the capital structure, loose monetary policy will increase the leverage ratio, which in turn will reduce the monitoring motivation, thus increasing the risk. Valencia uses a dynamic model to study the incentives for banks to improve risk-taking behavior under loose monetary policy conditions. When the risk-free rate falls, the bank will increase the proportion of loans due to lower financing costs and increased profits that monopolistic banks can receive from borrowers will increase the profitability of bank loans. In addition, capital requirements can be reduced but the incentives for bank risk exposure cannot be completely eliminated, as incentives for banks to over-risk when interest rates are low will increase [7] [8].

The monetary policy transmission channel refers to the central bank's use of open market operations, deposit reserve ratio, refinancing and rediscounting, benchmark interest rates, exchange rate policy and window guidance and other monetary policy tools to achieve the transmission mechanism and mechanism of monetary policy objectives. Traditional monetary policy transmission channels are divided into two types: monetary transmission channels and credit transmis- 
sion channels. However, traditional monetary policy channels have insufficient consideration of risk factors. To some extent, traditional monetary policy credit channels have certain links with risk-taking channels. Monetary policy risk-taking channels are measured from the perspective of credit quality. Policies affect banks' risk appetite and tolerance and thus change their credit delivery standards, which reflect the risks.

Specifically, the risk-taking channels have the following six transmission mechanisms:

1) Income and valuation effects: the impact of low interest rates on valuation, income and cash flow. The reduction in interest rates will drive up the rise in asset prices and collateral values, which will lead to an increase in bank risk identification and risk tolerance, which will undermine the default probability and loss rate. Adrian and Shin pointed out that loose monetary policy will increase the bank's assets relative to debt and lead to a decline in the leverage ratio, which will encourage banks to hold higher risk investments [9]. At the same time, they further pointed out that this adjustment of the bank on the balance sheet is based on changes in the risk measurement, which will amplify the cyclical movement of the economy [10].

2) Search for Yield: Another mechanism of action for monetary policy risk-taking channels is Rajan pursuit of revenue. Encourage asset managers to take on higher risks in a low interest rate environment [11]. Dell'Arriccia and Marquez found that low interest rates would reduce the problem of adverse selection, leading to more intense competition and credit expansion [12].

3) Competitive effect: Under the premise that other conditions remain unchanged, loose monetary policy will make the bank's competition more intense, reducing its marginal profit and deposit and loan spreads. In order to achieve the target income, banks may lower their lending standards and increase the proportion of risk assets in their portfolios, resulting in a decline in the value of bank concessions, which increases the possibility of bank failure.

4) Central Bank communication and its response: Monetary policy affects risk exposure through the characteristics of communication policies and the central bank's response function. The high degree of transparency and predictability of future monetary policy decisions will reduce market uncertainty, which reduces the risk premium and may lead banks to take on higher risks, which is the "transparency effect". Diamond and Rajan pointed out that when banks expect central banks to stimulate the economy and respond to negative shocks through loose monetary policy, they tend to take on higher risks [11].

5) Habit formation: The impact of monetary policy on risk taking can also be formed through habits. Habit is the state of the behavior of the investor over the past period of time, and will have a certain impact on the behavior at this stage. Campell and Cochrane found that agents tend to increase risk appetite when the economy rises, because their consumption will be higher than normal, so looser monetary policy will increase actual economic activity and reduce investor risk aversion [13]. 
6) Lever mechanism: The leverage ratio generally refers to the ratio of capital to the sum of capital and liabilities. Adrian and Shin found that financial institutions such as general commercial banks have fixed or pro-cyclical leverage rates. When interest rates fall, the value of the bank's capital relative to its debt increases, causing a drop in the leverage ratio [10]. Therefore, banks will respond to this decline by increasing their holdings of high-risk securities.

At the same time, more and more scholars analyze the relationship between low interest rate and bank's risk bearing behavior through empirical research, trying to clarify the characteristics of risk bearing channels. Angeloni et al. used the vector autoregressive model to provide the time series evidence of risk taking channels in the United States and Europe [14]. They found that falling interest rates in both America and the euro area had a significant positive effect on the risk to Banks' balance-sheets, whereas only in America did they have a positive effect on their leverage ratios. Altunbas et al. analyzed risk bearing channels based on balance sheet data of 643 listed Banks in the EU and the US from 1998 to 2008 [15]. Lopez et al. used the detailed information of consumer loans to examine whether there is risk taking behavior when Banks extend loans to households, so as to further compare the performance of risk taking channels in different types of loans [16] [17]. Zhang and he used the financial data of China from 2000 to 2010 to test the impact of China's monetary policy on bank risk taking by using the generalized moment method of dynamic panel system. The results show that monetary policy is not neutral, and monetary policy stance has a significant impact on bank risk taking [18] [19].

\section{Methodology and Variables Description}

\subsection{Methodology}

According to the above analysis of the influencing factors of the monetary policy risk-taking channel, this part builds a model to test the relationship between risk-taking and monetary policy of Chinese banks. If China does have a risk-taking channel for monetary policy, monetary policy will affect the bank's risk appetite, and loose monetary policy will increase the bank's risk appetite and tolerance. Since the bank's risk-taking preference and risk tolerance are generally sustainable, except for other influencing factors, the risk appetite of the previous period is also an important factor. Therefore, the lag of the risk variable should be introduced into the model period. At the same time, according to the influencing factors of the above-mentioned monetary policy risk-taking channels, the macroeconomic environment, the banking market structure, and the micro-variables of banks should all be included in the model. In summary, the factors are also based on the models of Delis and Kouretas and $\mathrm{Xu}$ and Chen [20] [21]. The panel data empirical model is established as follows:

$$
\text { Risk }_{i, t}=a_{0} \operatorname{Risk}_{i, t-1}+a_{1} \mathrm{MP}_{t}+a_{2} \mathrm{GDP}_{t}+a_{3} \operatorname{Bank}_{i t}+a_{4} \operatorname{Mar}_{i t}+v_{i}+u_{i t}
$$

where $i=1,2, \ldots N$ represent the data of the selected $N$ different banks, and $t$ represents the time of the data taken. The explained variable in the above for- 
mula is Risk, which measures the risk exposure of the bank. The most important explanatory variable is MP (Monetary Policy), which is the monetary policy proxy variable. GDP represents the macroeconomic situation, Bank represents the characteristic variable of the bank, and Mar represents the market structure of the banking industry. The parameter a represents the relationship between each explanatory variable and the bank's risk-taking situation.

The most important concern of this empirical model is the sign and significance of parameter $a_{1}$. If $a_{1}$ is significantly negative, it means that under other conditions, the monetary policy proxy variable is negatively correlated with the bank's risk-taking level. Specifically, the bank's risk-taking level is higher when the monetary policy is loose.

\subsection{Variables}

China's monetary policy tools can be divided into two major categories: quantity and price. The quantitative instruments mainly include deposit reserve ratio, open market, refinancing and rediscounting. The price type mainly refers to tools that focus on indirect regulation. It usually affects the economic behavior of markets and individuals through the structure of long-term and short-term interest rates. In foreign related literature, the interbank market interest rate is used more as a proxy variable of monetary policy. This is because with the expansion of its financial market capacity, the expansion of market players and the relative stability of the market equilibrium, Western countries' monetary policy tools have been adjusted from quantitative to price adjustment. However, China has not yet achieved full marketization of interest rates. In terms of monetary policy, it still focuses on quantitative currency instruments. Therefore, the negative value of the broad money M2 growth rate is chosen as the proxy variable of monetary policy, that is, MP in the model.

Commonly used bank risk measures include $Z$ value, non-performing loan ratio, franchise value, and expected default rate (EDF). Some foreign researchers such as Aggarwal and Jacques use the bank's risk-weighted assets and total assets [22]. The ratio between the two, and some researchers use the expected default rate or non-performing loan ratio (that is, the ratio of non-performing loans to total loans) to measure the level of risk exposure of banks. In theory, the expected default rate is a preferred measure of risk exposure and can be used as a proxy variable for risk. It refers to the probability of default of the lender within a certain period of time, and it is more sensitive to the early detection of default risk. However, China has not established a credit system. Therefore, in view of the availability of data, this paper chooses the bank's non-performing loan ratio as the Risk variable in the model to measure the bank's risk exposure.

In the economic boom, a loose economic environment may increase the willingness and level of bank risk taking, and the entire banking system will take on more risks. At the same time, when the economy goes up, enterprises will increase their investment and increase the demand for loans. Banks will adjust 
their credit standards accordingly. Therefore, macroeconomic conditions are also an important explanatory variable for bank risk exposure. Macroeconomic conditions are generally measured by GDP, consumer price indices, and real estate price growth rates. However, considering the economic situation in different regions of China and the price difference of real estate are large, and the real estate prices have soared due to certain factors in different periods, some real estate prices are not able to express China's actual macroeconomic conditions. However, it is only an investment bubble formed by capital flows, so this article does not choose real estate prices as a measure of macroeconomic conditions. At present, China's nominal GDP still maintains a large growth rate. Therefore, this paper chooses the growth rate of GDP as a measure of macroeconomic conditions.

In the literature review, some domestic and foreign studies have shown that the bank's size, capital adequacy ratio, profitability and other characteristics have made the bank's response to monetary policy different and thus affect its risk-taking behavior. Therefore, in the bank characteristic index Bank in the above model, the total assets of the bank (the total of liabilities and owner's equity in the data table) are selected to represent the size of the bank, reflecting the size of the bank and its risk-taking behavior and the relationship between the response to changes in monetary policy. At the same time, indicators should be selected to measure the bank's profitability. This is measured by the bank's total return on assets (ROA). The bank's capital adequacy ratio (Cap) is used to measure its capital adequacy level to verify the bank's micro-characteristics. The relationship is between monetary policy response and risk taking. Table 1 describes the meaning of variables and data processing methods:

$$
\begin{aligned}
\operatorname{Risk}_{i, t}= & a_{0} \operatorname{Risk}_{i, t-1}+a_{1} \mathrm{MP}_{t}+a_{2} \mathrm{GDP}_{t}+a_{3} \operatorname{Size}_{i, t-1}+a_{4} \operatorname{Roa}_{i, t-1}+a_{5} \operatorname{Cap}_{i, t-1} \\
& +v_{i}+u_{i t}
\end{aligned}
$$

The data selected for the above model is the annual dynamic panel data. The selected time interval is from 2004 to 2013. The sample objects include Bank of Communications, Bank of China, Industrial and Commercial Bank of China and China Construction Bank's four major state-owned banks (Agricultural Bank and it was officially listed in 2010, and the annual report data is less, so it is not included). There are also 11 large banks that have been listed, such as China

Table 1. Variables of the model.

\begin{tabular}{ccc}
\hline Variable & \\
\hline ROA & Characteristic variable of the bank & return on assets $\times 100$ \\
SIZE & Size of the banks & Log of total assets \\
RISK & Measuring Banks' risk-taking & non-performing loan ratio $\times 100$ \\
CAP & Characteristic variable of the bank & capital adequacy ratio $\times 100$ \\
M2 & Monetary policy & growth rate of M2 $\times 100$ \\
GDP & Marco-economic & growth rate of GDP
\end{tabular}


Merchants Bank, Shanghai Pudong Development Bank, Industrial Bank, and China Everbright Bank. The detailed data of these 15 banks are from the Wind database. The report types include A, B, C, and D. Here, the A type report representing "end of consolidation" is used. Some of these missing data are found through the public annual reports of banks. The macroeconomic and monetary policy data are derived from the National Monetary Market and Policy Tools database of the National Bureau of Statistics and the Cathay Pacific database.

\section{Empirical Finding}

Commonly used estimation methods are ordinary least squares (OLS), etc., but considering the variables with lag order in the model and the selected data are dynamic panel data, in order to get more accurate results of the real situation, refer to $\mathrm{Xu}$ and Chen, the estimation method adopted the GMM estimation method proposed by Arellano and Bond, namely the Generalized Method of Moments [23]. This method can relatively reduce the heteroscedasticity of endogenous problems and residuals, which does not require accurate distribution information of random error terms. Random error terms can have sequence correlation and heteroscedasticity, and thus the obtained parameter estimation is more effective, so it is also often used by research scholars at home and abroad.

Table 2 is descriptive statistics of the variables in the above model. In terms of macroeconomic conditions, the nominal gross domestic product (GDP) growth rate is the lowest at 8.55 in 2009 , the highest is at 22.88 in 2007; the maximum $\mathrm{m} 2$ for monetary policy is -14.39 in 2009 and the minimum is -27.58 in 2012. In terms of microdata of banks, the non-performing loan ratios among banks are quite different, with the standard deviation reaching 5.21 . The lowest is 0.33 in Ningbo Bank in 2006, and the largest is 30.66 in 2004 by Guangfa Bank. In terms of profitability measured by total return on assets, the maximum is ICBC's 2.7 in 2008, and the minimum is 0.02 in Nanjing Bank in 2004. The capital adequacy ratio was the largest in the Bank of Nanjing 2007 and the Everbright Bank in 2004-1.3.

Table 3 describes the estimated results of the coefficients and the relevant test coefficients. From the test results in the above table, we can see that the coefficient

Table 2. Descriptive statistics of data.

\begin{tabular}{cccccc}
\hline Variable & $\mathrm{N}$ & Mean & Sd & Max & Min \\
\hline ROA & 150 & 0.88 & 0.50 & 2.7 & 0.02 \\
SIZE & 150 & 13.96 & 1.51 & 16.68 & 9.67 \\
RISK & 150 & 3.42 & 5.21 & 30.66 & 0.33 \\
CAP & 150 & 10.84 & 3.77 & 30.14 & -1.3 \\
M2 & 150 & -18.12 & 0.14 & -14.39 & -27.58 \\
GDP & 150 & 15.82 & 0.18 & 22.88 & 8.55 \\
\hline
\end{tabular}


Table 3. Empirical result.

\begin{tabular}{cccc}
\hline & Parameter & Tvalue & Pvalue \\
\hline $\operatorname{RISK}(j, t-1)$ & $0.6926^{* * *}$ & 11.13 & $<0.001$ \\
$\operatorname{ROA}(j, t-1)$ & $-2.2442^{* * *}$ & -2.73 & 0.008 \\
$\operatorname{SIZE}(j, t-1)$ & $5.6436^{*}$ & 1.82 & 0.071 \\
$\operatorname{CAP}(j, t-1)$ & $9.2603^{* * *}$ & 7.52 & $<0.001$ \\
$\operatorname{M} 2(j, t)$ & $-1.6900^{* * *}$ & -9.90 & $<0.001$ \\
$\operatorname{GDP}(j, t)$ & $6.4179^{* * *}$ & 5.35 & $<0.001$ \\
$\operatorname{AR}(1)$ & & 0.001 & \\
$\operatorname{AR}(2)$ & & 0.668 & \\
$\operatorname{Sargan}$ & & 1.000 & \\
\hline
\end{tabular}

In the above table, ${ }^{*}{ }^{* *}$, and ${ }^{* *}$ represent the $10 \%, 5 \%$, and $1 \%$ significance levels, respectively.

of the proxy variable of the monetary policy (that is, the non-performing loan ratio of the bank) is significantly negative at the significant level of $1 \%$. Since the proxy variable of the monetary policy selects the negative of the M2 growth rate, Therefore, under the premise of controlling other characteristic variables of the bank, loose monetary policy will lead to an increase in the bank's non-performing loan ratio, which is to increase the bank's risk-taking, which indicates that China does have a risk-taking channel for monetary policy. At the same time, the nominal GDP coefficient is also positive. It also shows that when the macroeconomic situation is good, the bank will have an optimistic expectation of the future economic situation and enhance the tolerance of risk preference, which verifies the above-mentioned "habit formation" effect.

In terms of the characteristic variables of the bank, firstly, the coefficient of Cap representing the capital level of the bank is significantly positive, which indicates that the higher the capital adequacy ratio of the bank, the higher the risk. But this result is in stark contrast to the results of Xu and Chen (2012) and other studies. In their research, when China's bank capital adequacy ratio is high, its risk-taking will decline, so the capital adequacy ratio and risk-bearing are inversely related. Considering that the sample of empirical tests in its research is 59 commercial banks in China, including the listed banks including non-listed banks, the difference in results should be related to whether the selected samples are listed. At the same time, in combination with Yin, listed banks and non-listed banks were divided into two groups for empirical analysis [24] [25]. The results showed that the capital level coefficient of listed banks was significantly positive, and the capital level coefficient of non-listed banks was significantly negative. This may be due to the relatively high capital adequacy ratio of listed banks, so they have higher investment decision-making power while meeting regulatory requirements, and may have higher risk appetite in order to obtain higher returns. The non-listed banks themselves are not highly capitalized and subject to stricter supervision, so they will not be inclined to take high risks. On the other 
hand, the high capital adequacy ratio also reflects the bank's more cautious strategy and lower risk appetite. Secondly, the bank's risk-bearing is significantly negatively correlated with its profitability as measured by the total return on assets. This shows that the better the profitability, the lower the incentive for the bank to take risks, and the profitable banks have to take more risks to gain more. High-yield motives, so the risk exposure is relatively high.

\section{Conclusions}

This paper selects the data of 15 listed banks in China from 2007 to 2016, and uses the GMM estimation method of Arellano and Bond to conduct empirical research and obtain the following conclusions:

First of all, China's monetary policy risk-taking channels do exist, and loose monetary policies will encourage listed banks to take on higher risks. Different from the traditional credit channel, the risk-taking channel changes the bank's preference and tolerance for risk through changes in monetary policy, which in turn affects its risk-taking behavior. Secondly, according to the coefficient of GDP in the model, it is positive that the channel for monetary policy risk is affected by macroeconomic conditions. Specifically, the macroeconomic situation is positively correlated with the bank's risk-taking, which indicates that the "habit formation" effect does exist in China. Thirdly, the risk exposure of listed banks and the degree of response to changes in monetary policy will also be affected by their micro-characteristics. Specifically, banks with stronger profitability have lower risk appetite, while banks with weaker earnings have a preference for high risk in order to obtain higher returns.

Based on the analysis of the above experimental results and the relevant conclusions obtained, the following suggestions are proposed: firstly, when formulating monetary policy, the central bank should fully consider the relationship between monetary policy implementation and financial stability. Since monetary policy is non-neutral, monetary policy needs to be considered in a macro-prudential framework. From the perspective of the relationship between monetary policy and financial stability, the central bank needs to assume the responsibility of system regulators. Besides, according to the above conclusions, the bank's risk-taking behavior has a strong relationship with its own micro-features. The bank's capital adequacy ratio, profitability, size, etc. are all significantly related to the degree and level of risk-bearing preference. Different banks have obvious differences in their response to the same monetary policy and their risk-taking behaviors. Therefore, for different listed banks, the regulation should be based on its micro characteristics. At the same time, the bank's risk management monitoring system should be improved. Although the risk-taking channels of monetary policy have little impact on the economy relative to other traditional transmission mechanisms, avoid excessive relaxation of credit standards and excessive risk accumulation in the context of loose monetary policy. In turn, it affects the situation of financial stability and enhances its 
ability to resist risk shocks.

\section{Conflicts of Interest}

The author declares no conflicts of interest regarding the publication of this paper.

\section{References}

[1] Angeloni, I., Faia, E. and Duca, M.L. (2015) Monetary Policy and Risk Taking. Journal of Economic Dynamics \& Control, 52, 285-307.

https://doi.org/10.1016/j.jedc.2014.12.001

[2] The General Office of the State Council (2013) Guidelines on Financial Support for Economic Restructuring and Transformation and Upgrading. Chinese Financiers, No. 8, 17-19.

[3] Zhao, S. (2017) Research on the Existence of Risk Bearing Channels of Monetary Policy-From the Perspective of New Inter-Bank Business. Research on Technology Economy and Management, No. 7, 70-76.

[4] Borio, C. and Zhu, H. (2009) Capital Regulation, Risk-Taking and Monetary Policy: A Missing Link in the Transmission Mechanism? Journal of Heart \& Lung Transplantation the Official Publication of the International Society for Heart Transplantation, 8, 73-84.

[5] Dubecq, S., Mojon, B. and Ragot, X. (2009) Fuzzy Capital Requirements, Risk-Shifting and the Risk Taking Channel of Monetary Policy. https://doi.org/10.2139/ssrn.1630317

[6] Laeven, L., Dell'Ariccia, G. and Marquez, R. (2011) Monetary Policy, Leverage and Bank Risk Taking. Cepr Discussion Papers, 975-1009.

https://doi.org/10.2139/ssrn.1740763

[7] Valencia, F. (2014) Monetary Policy, Bank Leverage, and Financial Stability. Journal of Economic Dynamics and Control, 47, 20-38. https://doi.org/10.1016/j.jedc.2014.07.010

[8] De Nicolò, G., Dell'Ariccia, G., Laeven, L., et al. (2010) Monetary Policy and Bank Risk Taking. https://doi.org/10.2139/ssrn.1654582

[9] Adrian, T. and Shin, H.S. (2009) Money, Liquidity, and Monetary Policy. American Economic Review, 99, 600-605. https://doi.org/10.1257/aer.99.2.600

[10] Adrian, T. and Shin, H.S. (2010) Liquidity and Leverage. Journal of Financial Intermediation, 19, 418-437. https://doi.org/10.1016/j.jfi.2008.12.002

[11] Rajan, R.G. (2005) Has Financial Development Made the World Riskier? Social Science Electronic Publishing, NBER Working Paper No. 11728, 371-379. https://doi.org/10.3386/w11728

[12] Dell'Ariccia, G. and Marquez, R. (2006) Lending Booms and Lending Standards. The Journal of Finance, 61, 2511-2546. https://doi.org/10.1111/j.1540-6261.2006.01065.x

[13] Campbell, J.Y. and Cochrane, J.H. (1999) By Force of Habit: A Consumption-Based Explanation of Aggregate Stock Market Behavior. Journal of Political Economy, 107, 205-251. https://doi.org/10.1086/250059

[14] Angeloni, I. and Faia, E. (2013) Capital Regulation and Monetary Policy with Fragile Banks. Journal of Monetary Economics, 60, 311-324.

[15] Altunbas, Y., Gambacorta, L. and Marques-Ibanez, D. (2010) Does Monetary Policy 
Affect Bank Risk-Taking. https://doi.org/10.2139/ssrn.1577075

[16] López, M., Tenjo, F. and Zárate, H. (2011) The Risk-Taking Channel and Monetary Transmission Mechanism in Colombia. Ensayossobre Política Económica, 29, 212-234.

[17] López, M., Tenjo, F. and Zárate, H. (2012) The Risk-Taking Channelin Colombia Revisited. Ensayos Sobre Política Económica, 30, 274-295.

[18] Zhang, H. (2012) Monetary Policy Position and Bank Risk Taking: An Empirical Study Based on China's Banking Industry (2000-2010). Economic Research, No. 5, 31-44.

[19] Zhang, H. (2012) Risk-Taking Channels of Monetary Policy: Conduction Path, Asymmetry and Intrinsic Mechanism. Financial Review, No. 1, 71-81.

[20] Delis, M.D. and Kouretas, G.P. (2011) Interest Rates and Bank Risk-Taking. Journal of Banking \& Finance, 35, 840-855. https://doi.org/10.1016/j.jbankfin.2010.09.032

[21] Xu, C. (2012) Currency Environment, Capital Adequacy Ratio and Risk Acceptance of Commercial Banks. Financial Research, No. 7, 48-62.

[22] Aggarwal, R. and Jacques, K.T. (1998) Assessing the Impact of Prompt Corrective Action on Bank Capital and Risk. Economic Policy Review, 4, 23-32. https://doi.org/10.2139/ssrn.1024839

[23] Arellano, M. and Bond, S. (1991) Some Tests of Specification for Panel Data: Monte Carlo Evidence and an Application to Employment Equations. The Review of Economic Studies, 58, 277-297. https://doi.org/10.2307/2297968

[24] Yin (2013) Research on Risk Bearing Channels of Monetary Policy. Shandong University, Jinan.

[25] Jin, P. (2014) Bank Risk-Taking Channels, Monetary Policy and Macro-Prudential Supervision: Research Review and Outlook. Southern Finance, No. 8, 13-20. 